Корнелије Д. Квас

Универзитет у Београду, Филолошки факултет

\title{
РЕАЛИСТИЧКА МОТИВАЦИЈА, АКТУАЛИЗАМ И ПОСИБИЛИЗАМ
}

\begin{abstract}
Александар Илић одредио је реалистичку мотивацију као приповедање утемељено на паралелизму догађаја и ликова књижевног дела са збивањима и ликовима емпиријске стварности. Савремена теорија разликује актуализам, који даје онтолошко првенство стварном свету издвајајући га из скупа свих осталих могућих светова, и посибилизам, као онтолошко изједначавање стварног света унутар скупа свих осталих могућих светова. У раду се анализирају љубавне сцене у политичком контексту из Флоберовог романа Госпођа Бовари и романа Ситничарница „Код срећне руке“ Горана Петровића. Циљ рада је утврђивање релевантности актуализма и посибилизма, посебно у односу на реалистички књижевни поступак. Размишљања Александра Илића о односу стварности и фикције омогућавају разумевање савремених теорија актуализма и посибилизма.

Кључне речи: реализам, Александар Илић, Долежел, актуализам, посибилизам, Флобер, Горан Петровић.
\end{abstract}

\section{1. Реалистичка мотивација}

Као најважнију особину реалистичког поступка Александар Илић истиче реалистичку мотивацију у представљању збивања и ликова. Она се остварује „на основу одређеног паралелизма са збивањима и ликовима онако како теку и како се појављују и у емпиријски доживљеном свету“ (Илић 1984: 16). Следећи мисао Аристотела, али пре свега Томашевског, који пише да реалистичко приповедање претпоставља мотивацију засновану на принципу вероватности у односу на „одређену ситуацију“ (Томашевски 1972: 212), Илић уочава суштину поступка:

Реалистичку књижевну мотивацију усваја сваки читалац када у књижевним делима „препознаје“ оно што му личи на емпиријску, доживљену или емпиријско-рационално претпостављену, „вероватну и могућу“ стварност свакидашњице или друштва. Сви разликују бајку о вуку и Црвенкапи од приче о догађају који се стварно одиграо или могао одиграти у свету људског искуства. И у области такозване високе књижевности такође нема много двоумљења: и Бокачове и Борхесове приче јесу књижевно-уметничка

kornelije.kvas@fil.bg.ac.rs 
остварења, новостворени светови речи, имагинације и интерпретације, али је разлика у књижевној мотивацији, у методу, поступку, стилу, веома упадљива - код Бокача све углавном тече онако како је и могло тећи у ренесансној свакидашњици; код Борхеса је на делу сасвим другачија, фантастична, надреална, мистичносимболична књижевна мотивација (Илић 1984: 17).

Илић одбацује механичку поделу на реализам и фантастику. Подсећа да се Достојевски, у оквирима књижевног стваралаштва, противио успостављању чврсте и непремостиве границе између света (емпиријске) стварности и света маште, сматрајући да је „таква подела једнострана, механичка, супротна самој природи стварности“. У писму А. Н. Мајкову („Мој идеализам је реалнији од њиховог реализма“) „Достојевски је одбацио вештачку поделу књижевног света на два дела: реалистички, у којем се „репродукује“ стварност, и идеалистички, у којем пребивају идеје и представе, творевине људског духа“ (исто: 12).

Достојевски и Флобер одредили су позитивистички схваћени реализам као рђаву естетику, знајући да се „књижевно, уметничко обликовање не може олако свести на „репродуковање“ и „одражавање“ (исто). У повезивању миметичког и фикционалног, уочава Илић, налази се „скривена трајна привлачност реалистичке доктрине у њеном најбољем издању, као и самог реалистичког књижевног поступка“ (Илић 2016: 253). Ставови Александра Илића о реалистичком поступку, мотивацији и односу стварности и фикције омогућавају боље и прецизније разумевање савремених теорија актуализма и посибилизма.

\section{2. Мимеза као имитација, универзалистичка} мимеза, псеудомимеза

Разумевање односа фикције и стварности, реалистичке и фантастичке мотивације, чврсто је повезано са разумевањем појма мимезе. Лубомир Долежел разликује три историјске фазе у разумевању средишњег поетичког појма европске цивилизације. У првој фази, коју обележава Платоново схватање мимезе, мимеза је поступак уметничког имитирања, подражавања стварносног ентитета, па можемо говорити о мимези као имитацији. Проблем настаје када уметнички (фикционални) ентитет нема свог парњака у стварности. Аристотел га решава универзалистичким схватањем мимезе - фикционални ентитети нису више или нису само имитација стварносних, већ су пре свега представљање стварносних општости, као што су друштвене 
групе, карактерни (психолошки) типови, друштвено-историјске околности, начини на који функционише људски свет. У оквиру универзалистичког схватања мимезе Долежел уочава проблем губитка (семантичке) независности фикционалних ентитета, због њиховог поистовећивања са универзалијама које суштински остају у стварносним оквирима. Посебност фикционалних ентитета нестаје, што је у супротности са изворном Аристотеловом идејом о аутономности миметичког (уметничког) дискурса у односу на стварност, али и друге дискурсе (реторички, дијалектички, аподиктички). ${ }^{1}$ Трећу, савремену фазу, Долежел обележава као псеудомиметичку. Фикција је старија од стварности, она јој претходи и актуализује се чином уметничког стваралаштва. Првобитно схватање мимезе потпуно је поништено. Псеудомимеза подсећа на Лајбницову метафизичку теорију могућих светова: у божанском уму постоји неограничени број могућих светова које надахнути ум може актуализовати.

\section{3. Актуализам и посибилизам}

Одређујући реалистичку мотивацију на основу начела паралелизма догађаја и ликова фикционалног света са догађајима и начинима поступања људи у стварности, Илић даје онтолошко првенство стварном у односу на свет уметничке фикције. Његово схватање остаје у оквирима универзалистичког схватања мимезе. Свестан могућности губљења аутономије уметности у односу на науку, друге духовне делатности или емпиријску стварност, он истиче ставове великих реалистичких писаца, Достојевског и Флобера, који издвајају важност успеле форме књижевног дела, која чува аутономност дела доприносећи његовој вредности. Као најважнију формалну особину књижевног дела Аристотел поставља фабулу, а Флобер стил.

Традиционално становиште, по коме стварни свет има онтолошку предност у односу на свет фикције, уочавамо још код

1 По Аристотелу, наведени дискурси равноправни су у долажењу до истине, али међу њима постоји квалитативна разлика. Платон је једино у дијалектичком дискурсу видео могућност долажења до истине, док Аристотел сматра да дијалектика води једино до вероватног знања. Реторски дискурс, тврди Стагиранин, заснован је на контингенцији, као модалитету који нуди могућност долажења до истине. Песнички дискурс заснован је на мимези, способности која је сваком човеку урођена, и она, у најбољим уметничким делима, остварује вероватно или нужно сазнање. Једино путем аподиктичког (научног) дискурса, учи нас Аристотел, нужно долазимо до знања и истине (Kvas 2011: 126-127). 
Платона: уметност је по својој природи увек и само миметичка, она може копирати једино стварни, док је свет идеја за њу недостижан. Аристотел мења садржину појма мимезе, која има могућност представљања универзалног или света идеја, које више нису, као код Платона, изван или изнад стварности, већ су потенцијално у њој присутне. Мишљење које стварности даје онтолошку предност у односу на светове фикције, издвајајући је из скупа свих других могућих светова, Лубомир Долежел означава као актуализам (Долежел 2008: 25).

Псеудомиметичко схватање уметности довело је до релативизације онтолошког статуса стварности. Могући светови су онтолошки надређени или равноправни стварном свету - њихово постојање независно је од субјекта стварности. Актуалан није само стваран свет, већ је сваки свет (и стварни и могући) актуалан за становнике тог света. По Луисовој теорији модалног реализма, „'актуално' је индексно, као што је 'ја' или 'овде' или 'сада': зависи од тога на шта се односе околности изговарања, односно од света у коме се изјава налази“ (Lewis 1979: 184). Сваки свет је по себи актуалан и самим тим онтолошки вредан. Такво стајалиште Долежел именује као посибилизам - стварни свет онтолошки је равноправан са другим могућим световима. Стваран свет стваран је („real“) колико и сви други могући (фикционални) светови. Стварност се одређује из позиције становника тог света. Становник га актуализује и уколико је за њега стваран, неко ван његовог света ту стварност не може оспорити. Рајанова о томе износи следеће гледиште:

У Луисовој индексној теорији, сваки могући свет је стваран [real], и сваки могући свет може бити актуалан [actual], али ова два термина, која се често наизменично користе, нису синоними. „Бити актуалан“ значи: „постојати у свету из кога говорим“. Алтернативни могући светови (AMC) не могу бити актуални за мене, јер их разматрам са друге планете у универзуму могућности. Стога могу говорити о неактуалним могућим световима и неактуалним могућностима. Али уколико постоје апсолутно, AMC су стварни, и свака могућност се остварује у неком свету (Ryan 1991: 18).

Долежел постојано указује на разлику између актуализма и посибилизма. Актуалистичко становиште претпоставља свет чије постојање се може емпиријски утврдити - то је стварни свет при чему су сви остали могући светови производи људског ума (Долежел 1980a: 10). 
Здраворазумско становиште тешко да може прихватити претпоставку о онтолошкој равноправности света стварности и могућих светова, па тако и светова фикције. За заступнике посибилизма, фикционални свет бајке Црвенкапа - подсетимо се за тренутак примера Александра Илића - подједнако је стваран као и свет емпиријске стварности читаоца бајке. Уколико желимо да се сагласимо са заступницима посибилизма, треба поверовати да је свет Црвенкапе актуалан за његове становнике (Црвенкапу, вука и друге ликове).

Актуалистички приступ фикционални свет Црвенкапе одређује као бајку, зато што, између осталог, у (емпиријској) стварности животиње не причају, нити из стомака вука ловац може да извади живу и неповређену девојчицу и њену баку. Књижевно стваралаштво не може се „олако свести на 'репродуковање' и 'одражавање'“ (Илић 1984: 12). Од степена подударања са емпиријском стварношћу, за књижевну уметност много су важније формалне, уметничке одлике дела. Проблем посибилизма и актуализма зато ћемо размотрити упоредном анализом љубавних сцена у политичком контексту у романима Госпођа Бовари Гистава Флобера и Ситничарница „Код срећне руке“ Горана Петровића.

\section{4. Љубав и политички дискурс: Госпођа Бовари и Ситничарница „Код срећне руке“}

\section{1. Госпођа Бовари}

У Флоберовом роману Госпођа Бовари издваја се сцена пољопривредног сајма (представљена у осмој глави другог дела романа) у којој се Родолф удвара Еми Бовари. Сцена обилује особеностима Флоберовог реалистичког поступка: у оквире верног представљања пољопривредне скупштине у француској провинцији 19. века уткана је сцена завођења јунакиње романа, у којој се сентиментални дискурс прекида и преиначава политичким. Речима заводника сентиментални дискурс унапред је одређен као политички. Успостављена је двострука дистанцираност приповедача према сентименталном говору. Политички дискурс је преовлађујући, док је сентиментални потиснут. Како је у роману присутна реалистичка књижевна мотивација, реч је о актуалистичком схватању стварности и уметности, јер свет (друштвене) стварности у којој доминирају лични, политички и економски интереси - има првенство у односу на свет емоција и маште, који 
је, посебно у случају јунакиње Флоберовог романа, последица њене лектире, љубавних и историјских романа:

У тим романима говорило се само о љубави, о љубавницима, о милосницама, о гоњеним госпама које падају у несвест у усамљеним павиљонима, о постиљонима који гину на сваком кораку, о коњима који се сатиру на свакој страни књиге, о мрачним шумама, о узбуђењима срца, о заклетвама, о уздасима, о сузама и пољупцима, о чуновима на месечини, о славујима по луговима, о господи која су храбра као лавови, кротка као јагањци, препуна врлина, увек лепо одевена, и који плачу као урне. [...] Живела би радо у каквом старом замку, као оне властелинке дугачког струка, које под готским сводовима, с лактом на камену и с брадом наслоњеном на руку, проводе дане гледајући како из даљине долази коњаник с белим пером, који галопира на црноме коњу (Flober 2015: 38-39).

Увод у Родолфово удварање и мотивација његових поступака дати су на крају седме главе другог дела романа. Тридесет четворогодишњи господин Родолф Буланже шета пољем испод топола и размишља о Еми и њеном супругу, док га она из даљине посматра. Родолф процењује да је Емин муж глуп, неуредан и досадан. Назире да поред таквог мужа она жуди за љубавном авантуром и да ће му за остварење подухвата бити довољно неколико „љубазних речи“ (исто: 119). Пореди Ему са својом љубавницом, глумицом из Руана, коју је издржавао:

'Ax! Госпођа Бовари је', помисли он, 'много лепша од ње, нарочито свежија. Вирџинија збиља почиње да бива исувише дебела. Тако је досадна са својом љубављу. Па онда оно њено лудовање за раковима' (исто).

Замишља Ему и поче је у „мислима свлачити“. Одлучује да мора бити његова и свестан је да треба да „пређе на политичку страну $^{2}$ овог подухвата“ (исто). Да би удварање било успешно, мораће да Еми приђе на неком неутралном месту, ван њене куће, мимо мужа, дадиље, детета, суседа. Предстојећа скупштина пољопривредника право је место за остварење његових намера.

У Јонвилу је почео дуго очекивани скуп пољопривредника. Присутна је народна гарда и локални ватрогасци. Приповедач детаљно описује уређивање и украшавање села и становника: куће су опране и окићене тробојкама, сељани дотерани и лепо обучени у тој мери да „никад није било толико спољашњег сјаја“ (исто: 120). Нарочиту пажњу изазвала је раскошна трибина подигнута

2 Подвукао К. Квас. 
за политичаре, као и четири заставице уз општинску зграду са натписима: „Трговини“, „Земљорадњи“, „Индустрији“ и „Лепим вештинама“" (исто: 121).

У Флоберовом уметничком поступку представљање детаља има другачију функцију у односу на претходне реалистичке приповедаче. Детаљи добијају службу ауторског коментара, градећи интерпретативни оквир који омогућава тумачење из текста романа. Приповедач посредно и неприметно води читаочево разумевање текста ка смислу. Пре, а и после Флобера, упућивање читаоца на жељени смисао остваривано је приповедачким коментаром ликова и њихових поступака. Зато је опис пољопривредног сајма прекинут разговором крчмарице и апотекара Омеа, који је убеђује како је он стручњак и за пољопривреду, пошто је врсни хемичар! Она га не слуша, већ скреће разговор на власника супарничке кафане коме прети банкрот, јер га је Лере „сатро“ меницама (исто: 123). То је податак важан за будућу, трагичну судбину Eме Бовари, јер ће и њу сасвим уништити дугови. Она ће, позивајући се на њихову љубав, у осмој глави трећег дела романа безуспешно тражити од Родолфа позајмицу од три хиљаде франака, како би избегла пописивање и одношење покућства. Сада, на дан пољопривредног вашара, њена судбина је само овлаш назначена, јер осуђујући Лереа крчмарица примећује како се он у том тренутку налази на пијаци: „јавља се госпођи Бовари, која је у зеленом шеширу; и штавише иде подруку с господином Буланжеом“ (исто). Следи детаљан опис Еминог изгледа који истицањем детаља и приближавањем метонимијском полу језика представља њену лепоту:

Њено је лице било тако мирно да се на њему ништа није могло приметити. Оно се у пуној светлости издвајаше под облим шеширом с бледим тракама које су личиле на лишће од трске. Њене очи с дугачким повијеним обрвама гледале су преда се, и мада су биле врло отворене, код јагодица су изгледале нешто затегнуте, због крви која је благо струјала под нежном кожом. Румена боја беше облила преграду њена носа. Она је нагињала главу на раме, и између усана видео јој се седефасти крај белих зуба (исто: 123).

Родолф успева да се отараси досадног и насртљивог Лереа. Уочивши маргарете у трави отпочиње удварање у складу са матрицом Емине лектире - љубавних и сентименталних романа. Изјављује како постоје многобројна пророчанства везана за маргарете и заљубљене девојке и предлаже Еми да јој убере једну. Она му одговара обртањем скривеног питања: „Зар сте ви 
заљубљени?“ (исто: 124). Родолф не одбацује ту могућност, настављајући игру завођења удате жене.

Опис јонвилских жена у функцији је уздизања пара ЕмаРодолф изнад прозаичности сеоске свакодневице, јер се често требало уклањати „испред дугачког низа сељанки, слушкиња у плавим чарапама, с незграпним ципелама са сребрним прстењем, и које су, кад се поред њих прође, мирисале на млеко“ (исто: 124). Родолф исмева пољопривредну изложбу а посебно се руга „јонвилским женама због њихова одела“ (исто: 125). Одмах након ругања, извињавао се Еми због сопственог несавршеног одевања. На тај начин он показује надмоћ над паланачким обичајима, док његова гардероба, супротно његовим речима, показује стил који далеко надмашује паланачки начин одевања:

Тако, његова кошуља од батиста с набраним зарукављем надувала се према ветру, на грудима, кроз раскопчани прсник, који је био од сура цвилиха; а његове панталоне са широким пругама падале су до чланака на ципеле од нанкина, обложене лакованом кожом. Оне беху тако сјајне, да се на њима трава огледала. У њима је он газио по коњској балези, држећи једну руку у џепу прсника, а сламени шешир накривљен на уво (исто).

Флоберова наративна перспектива ограничена је на одређени број тачака гледишта и тиме француски писац избегава употребу свезнајућег приповедача. Најчешће се приповеда из Емине перспективе, која и на тај начин заслужује епитет главне јунакиње. Контраст између сјајних, лакованих ципела и коњске балеге у коју непрестано упадају - гради имплицитни ауторски коментар: у Еминим очима, јединим које прате ту сцену, Родолф је узвишени лик који гази по прљавштини и неукусу паланачког живота. Зато она „поче говорити о паланачкој простоти, о бићима која она гуши, о лепим сновима који се у њој губе“ (исто). Родолф јој „признаје“ да је он због тога све суморнији, да би применио реторику и стилска средства романтизма, посебно сентименталних романа: гробље и месечину. Његова веселост је привид, исповеда се Родолф, настављајући речима: „пред светом умем да носим на лицу подругљиву образину; међутим, кад погледам гробље, на месечини, колико сам се пута питао не бих ли боље учинио да одем онима који почивају ..." (исто: 125-126). Ема на то примећује како је он слободан и богат човек, који у животу нема за чим да жали. Родолфова игра завођења успешно прати матрицу Емине лектире и она се све више приближава тренутку када ће госпођи Бовари открити своја осећања. 
Родолф и Ема пењу се на први спрат општинског здања, да би из једне од сала уживали у предстојећем догађају. Гледају на трибину на којој се налази господин саветник Лијевен, који чита говор. Док се нижу хвалоспеви управи, влади и монарху, Родолф предлаже Еми да се склони, како га не би уочили у Емином друштву, јер га бије рђав глас. Смењују се речи политичара, који хвали успехе владе у изградњи путева и фабрика, са речима политичара-заводника о срећи коју човек једном налази у животу:

Хоризонт се тада отвара и неки глас као да виче: „Ево је!“ Ви осећате потребу да тој личности исповедите свој живот, да јој дате свој живот, све, да јој жртвујете све! Ви се не објашњавате, ви се разумете. Виђате се узајамно у сновима. (И он је погледа.) Укратко, то благо које сте толико тражили ту је, пред вама; оно се сија, блиста. Међутим, ви још сумњате, не смете чисто да верујете; остајете засењени као да сте из мрака изашли на светлост (исто: 129).

Док саветник наставља да чита говор о важности пољопривреде и посебно земљорадње, која доприноси напретку државе и појединца, Родолф убеђује Ему да се препусти страстима: „Нису ли оне једино што је на овој земљи извор јунаштва, одушевљења, поезије, музике, уметности, једном речју - свега?“ Ема се брине како ће друштво реаговати на такво препуштање страстима. Родолф има спреман одговор. Постоје две врсте морала. Први је „ситничарски, извештачени морал, морал људи, онај који се мења непрестано и који толико урла, комеша се, вуче по земљи, као овај скуп глупака који видите“. Други је морал „вечити, он је свуда око нас и изнад нас, као предео који нас окружује и плаво небо које нас обасјава“ (исто: 130). Господин Лијевен је све време говорио, свет је слушао, а разумљивост његових речи прекидало је „отегнуто рикање волова или блејање јагањаца, који су одговарали једно другоме на углу улица“ (исто: 131).

Родолф се сасвим приближио Еми говорећи јој о емоцијама две сродне душе које ће се спојити у љубави. Гледајући га у очи, Ема се сетила виконта с којим је плесала у Вобисару. Спазила је поштанска кола Ласта којима јој је Леон често долазио у посету; обузимају је осећања, док монотони глас саветника наставља да говори о важности ђубрења и развијања нових раса коња, говеда, свиња и оваца. Прагматични свет свакодневице у таласима се обрушава и преклапа сентиментално језерце Еминих пробуђених осећања. Стварност надвладава свет Еминих емоција подстакнутих Родолфовим речима, али и речима прочитаних љубавних романа. Актуализам не дозвољава могућност појаве принца који 
ће удату жену из француске провинције одвести у свет вечите и страсне љубави.

Приповедач изненада појачава учесталост смењивања политичко-заводничког и политичких говора. Два су посредна разлога за промену ритма: Родолфово завођење приближава се кулминацији, а саветника Лијевена за говорницом је сменио председник Дерозре:

док је господин председник помињао Цинцината за његовим плугом, Диоклецијана како сади купус, и кинеске цареве који су свечано објављивали почетак године сејањем, дотле је млади човек објашњавао младој жени да узрок овој неодољивој привлачној сили ваља тражити у неком ранијем животу (исто: 133).

У почетку су се међусобно борили, надјачавали и смењивали пасуси Родолфовог и саветниковог излагања, да би у кулминацији игре завођења Еме и завођења гласача дошло до брзе измене Родолфових и председникових реченица, па и речи:

И он је узе за руку; она је не трже.

„Награда за укупно газдинство!“, викну председник.

- Малопре, на пример, кад сам дошао к вама...

„Господину Бизеу из Кенканпоа.“

- Јесам ли знао да ћу вас пратити?

„Седамдесет франака!“

- Штавише, сто пута сам хтео да одем, па сам ишао за вама, остао сам.

„За ђубриво.“

- Као што бих остао вечерас, сутра, других дана, целог живота!“

„Господину Карону из Аргеја, златна медаља!“

- Јер ја никад ни у чијем друштву нисам нашао тако потпуну драж.“

„Господину Бену из Живри Сен Мартена!“

- Зато ћу и понети успомену на вас.

„За мерино-овна...“

- Али ви ћете ме заборавити, ја ћу бити за вас као сенка која је прошла.

„Господину Белоу из Нотрдама...“

- Ox! Не, је л'те, ја ћу бити нешто у вашим мислима, у вашем животу?

„За расу свиња, награда ех аеqио: господи Лерисеу и Киламбуру, шездесет франака!“" (исто) 
Родолф јој стеже руку док она покушава да је ослободи. Њен покрет прстима он гласно тумачи као пристанак. И док се чује испрекидани председников говор о ђубрењу, обрађивању лана и исушивању бара, „њихове суве усне дрхтале су од превелике чежње; и благо без усиљавања, њихови се прсти сјединише“ (исто: 134).

\section{2. Ситничарница „Код срећне руке“}

У роману Горана Петровића Ситничарница „Код срећне руке“ главни јунак Анастас Браница пише епистоларни роман Францускињи Натали Увил. Писма оставља у Француско-српској читаоници у Кнез Михаиловој улици непосредно пред долазак кћерке француског инжењера Увила. Она у читаоницу долази у пратњи патронесе Дидије и у књизи налази дупликат писма, јер је Анастас претходне вечери, у својој кући „полагао испред себе по два испресавијана арака папира, расецао их и на оба низао исти садржај, гледајући да ни за реч нема одступања, ни за тачку отклона“ (Петровић 2001: 169). Анастас и Натали познају се једино преко писама, тако што их истовремено читају. Мада одвојени реалним простором, они се сусрећу у фикционалном свету романа. У складу са теоријом посибилизма, фикционални простор је равноправан, па чак и надређен стварном. Натали постаје све хладнија према господину Шампену, удварачу који је посећује у „стварном“ простору романа Ситничарница „Код срећне руке“, а све приснија са удварачем који јој прилази у свету епистоларног романа. Књижевни лик, Анастас Браница, у фикционалном свету Петровићевог романа ствара фикционални простор у коме је његова љубав према Натали могућа и остварива.

Како је време одмицало, писма су све више била испуњена „љубавним осећањима и етеричним изјавама“. Млади писац и љубавник трудио се да у српском језику пронађе што поетичније речи и „романтичне склопове“ (исто: 170), помажући се и француском поезијом. У свету епистоларног романа двоје младих и разговарају:

- Анастасе, шта је ово?

- Роман. Биће то роман са нама као јединим ликовима. Обиман роман, са срећним крајем... - осмехнуо се он и поносно испрсио.

- Заиста? - питала је, бојећи се да не трепне, да га ни трептајем не прекине. 
- Да. Видећете. Све ћу уредити за нас двоје. На вама је само да захтевате шта желите... (исто: 172).

Наведени дијалог не мора бити пример сусрета „стварног“ Анастаса и „стварне“ Натали у свету фикције. Дијалог може бити део Анастасовог писма; њих двоје не разговарају док истовремено читају роман, него је разговор већ предвиђен и написан у писму. Да је то ипак могуће и да је роман написан под снажним утицајем постмодернистичке поетике показује то што љубавници трагове својих сусрета у фикцији доносе у „стварни“ свет:

Истина, повремено се Анастасу Браници и Натали Увил, заједно, чинило - да је њихова романса само причина. Појединачно - да он, односно она, не постоји, да су једно друго измаштали. Повремено им се тако чинило, да би их трагови њихове љубави оповргавали, уверавали. Наиме, бивало је да се Анастас врати длана умрљаног пастелним кредама, оног длана у којем је држао руку вољене. Бивало је да она, после читања, затекне на својим прстима несумњиво његове мрље љубичастог мастила (исто: 180).

Анастас у свом роману речима гради вилу, врт и стаклени павиљон. Када је вила, након две године градње, 1930. године коначно добила кров, створен је простор у коме су љубавници могли дуже и чешће да бораве. Након читања једног писма у својој кући на Сењаку, Натали примети „трагове љубичастог мастила на сваком појединачном дугмету“ своје хаљине. Како би од своје старатељице сакрила трагове сусрета са младићем, она „пожури да се пресвуче, откривши одразе Анастасових мастиљавих јагодица на чарапама, од колена навише, откривши их на свом рубљу, а када и све то скиде, до наготе, исте отиске нађе на кожи, на белини груди, трбуха и бокова...“ У својој кући на Звездари, која за фикцију Браничиног епистоларног романа представља „стварни“ простор, писац-љубавник открива „трагове пастелних креда около дугмади своје кошуље“. Као и његова љубавница, он свлачи кошуљу и на свом телу уочава „овлашне или пуне отиске пастелних јагодица, свугде оне боје примерене одређеном делу тела, понајвише црвених нијанси, од стидљиворужичасте до пурпурнокључале... (исто: 181). Свет епистоларног романа (виле, врта, стакленог павиљона) јесте алтернативни могући свет (AMC) и актуалан је - стваран - за његове становнике, јунаке и читаоце тог романа који су истовремено ликови романа Ситничарница „Код срећне руке“. Тај свет не може бити актуалан за мене и друге читаоце Петровићевог романа, јер га 
посматрамо са „друге планете у универзуму могућности“ (Ryan 1991: 18).

Писац Горан Петровић примењује поступак троструке фигурације: 1) користећи реалистичку мотивацију ствара фикционални свет романа и фикционалне ликове, међу њима Анастаса и Натали; њихови ликови су „стварни“. 2) Главни лик Анастас Браница, писац је и читалац; пише епистоларни роман, како би себи омогућио да се у том, другостепеном фикционалном свету, сусреће са својом драгом Натали Увил. У тај свет улазе и други ликови Петровићевог романа - читаоци романа Анастаса Бранице. 3) Трећу фигурацију врше читаоци Петровићевог романа, који су остварили и првостепену фигурацију. Они прву и другу фигурацију обједињују у једну целину, на тај начин остварујући трећу фигурацију или рефигурацију (3) фигурација $(1,2)$.

У четрдесет петом поглављу романа Ситничарница „Код срећне руке“ сударају се фикција и „стварност“ или фикција фикције и фикција стварности. Као и у сцени пољопривредног сајма из осме главе другог дела романа Госпођа Бовари контекст је политички, чиме се наглашава референтна, емпиријска стварност. И у Флоберовом и у Петровићевом роману љубавну сцену пресецају одломци политичког говора. Пре тога, у последњем пасусу претходног, четрдесет и четвртог поглавља, приповедач упозорава на последице уплитања „стварности“ (1) у фикционални свет епистоларног романа Анастаса Бранице (2):

Свакако, тако би се седмична писма вољеној ко зна докле низала, до у бесконачност, Анастас Браница није презао да се уложи до одсуства даха или да укупно своје земно имање утроши до последње паре, биће да би тако било - да се у све није подмукло завукла стварност (Петровић 2001: 209).

Приповедач описује Калемегдански парк за време обележавања годишњице од завршетка Првог светског рата. Браница, живећи у свету свог романа у коме се састаје са љубљеном Натали, није ни знао да се те суботе на Калемегдану окупљају политичари, војници и државни великодостојници. Намеравао је да након испијене кафе са циметом у „Руском цару“ прошета кратко Калемегданом, а онда оде кући како би завршио писмо. Затиче мноштво света и гардијски оркестар који свира химне савезница, Француске и Србије. Министар иностраних послова Краљевине Југославије, заједно са француским послаником, полагао је, уз постамент Споменика захвалности Француској, „ловоров венац“ 
(исто: 210). Следи реалистички опис „стварности“ - обележавања годишњице великог историјског догађаја:

Два ђенерала, српски и француски, у пратњи неколицине високих официра савезничких земаља, у нацифраним униформама, са парадним сабљама, спремали су се да учине исто. Десетине учесника повлачења преко Албаније и славних битака, празнично избријани или уфитиљених бркова, прса украшених светлуцањем ордења и медаља за храброст, поздрављали су у ставу мирно. Многи угледници, на челу са горостасном појавом патријарха Варнаве и блажено мирним бискупом, госпође и господа, смерне штићенице пансиона „Saint Joseph“, ожалошћене породице оних који се нису вратили, бројни француски ђаци, увеличавали су својим присуством свечани чин (исто: 210-211).

Поред Анастаса Бранице, обавештава нас приповедач, прође и писац Станислав Винавер, и поздрави га. Браница се примаче споменику како би боље чуо министров политички говор. Слушајући га, сетио се свог учешћа у рату у својству обавештајца француске команде. У реалистичко приповедање уплиће се и фантастичка мотивација; приповедач упознаје читаоца да је Браница читао војне мапе и да

умало није страдао, пошто се погодило да једну карту, подручја офанзивних операција Солунског фронта на линији Соко - Добро Поље - Ветерник, тумачи у једнако време када и непријатељска служба са истим задатком (исто: 211).

Читање војних карти у реалистичком дискурсу пресеца фантастички дискурс, у коме је могуће да се просторно удаљени тумачи мапа сретну и сукобе у свету фикције (простору тумачених мапа). Доказ да се то „стварно“ догодило је ожиљак на левој веђи Анастаса Бранице.

Док се трудио да прати министров говор он „наједном, поставши свестан познатог мириса, изнутра уздрхта“ (исто). Никада је раније не сусревши у „стварности“, знао је ко је поред њега: била је то Натали, на два корака од њега, у обавезном друштву мадам Дидије. Анастас препознаје Натали из свог романа. Приповедач се и даље служи реалистичким описом, постављеним између два одломка министровог говора (... племенитом народу Републике, чија нас је Влада несебично помагала, прихвативши... [...] ... у часу када нам је било најпотребније... (исто: 211-212):

Јесте, то је њен витки врат, колико пре неки дан га је додиривао. Јесте, то је њено љупко уво, толико је пута шапатом благо ми- 
ловао добро знане завоје ушне шкољке, све док се Натали не би стресла (исто: 212).

Синтагме „витки врат“, „љупко уво“, „ушне шкољке“ метонимијски упућују на девојку, појачавајући повезаност елемента у наведеном исказу и повезаност исказа са контекстом, ${ }^{3}$ који је двоструко измењен у односу на традиционално реалистичко приповедање. Уместо контекста стварности, контекст је фикционалност фикције $(1,2)$ :

Јесте, нема сумње, то је она... Анастаса проби врућина. Били су и ближи у његовим згуснутим редовима, али се ван писама никада нису сусрели, поготово не тако, надохват руке. Шта да ради? Како да се понаша? Уплићу ли се то два далека света, један замишљен, други стваран? Сустичу ли се, најзад, напоредна времена у праву меру постојања? (исто)

За Браницу, свет његовог романа (фикција фикције) равноправан је свету „стварности“ Петровићевог романа (фикцији) и у том смислу теорија посибилизма је разумљива и одржива. Реакција Натали Увил поново успоставља доминацију „стварности“ у односу на фикцију - оснажујући теорију актуализма. Она уочава младића „озбиљно одевеног, паперјасте браде и бркова, са ожиљком попреко леве веђе, све у свему веома познатог“ (исто). Она није могла да се присети одакле га познаје, јер је њена перцепција околине изграђена на основу „паралелизма са збивањима и ликовима онако како теку и како се појављују и у емпиријски доживљеном свету“ (Илић 1984: 16). За њу је то обичан déjà vu, погрешан утисак да је особу већ видела: „учини јој се да је тај човек - сличан лику који се годинама понавља на њеним цртежима, оним рађеним пастелом, по мотивима из књижевних дела“. Натали одбацује ту могућност речима да „то није могуће“ (Петровић 2001: 212). Стварност је онтолошки старија од фикције, и зато „није могуће“, тврди књижевни лик Петровићевог романа, Натали Увил, да фикционални ликови улазе у „стварност“ сусрећући се са „стварним“ особама. На исти начин, други фикционални лик романа Ситничарница „Код срећне руке“ Горана Петровића, Анастас Браница, дубоко верује да је тај прелазак остварив.

3 У тексту „Два аспекта језика и две врсте афазичких сметњи“ (Jakobson 1986) Јакобсон разликује метафоричну и метонимијску функцију језика. Он издваја метафору и метонимију као два основна принципа функционисања језика, усклађена са односима селекције и комбинације. Селекцију повезује са језичком функцијом супституције остварену метафоричким односима, док је комбинација усмерена на стварање контекста и повезаност елемената у поруци, остварену метонимијским односима. Метафорички односи присутнији су у симболизму и романтизму, метонимијски у реализму. 
Приповедање је и даље испресецано политичким говором, који помера тешко успостављену и крхку равнотежу фикције и „стварности“ на стварносну страну. Анастас је ужаснут сазнањем да га вољена овде, у „стварности“ не познаје, док га тамо, у фикцији његовог стваралачког умећа - воли. Коначну превагу стварности означава поступак мадам Дидије; приметивши простачки насртљиво пиљење непознатог младића у штићеницу, узела је госпођицу Увил за руку и повукла је у страну. Натали је изговорила само једно „Рardon“ (исто: 214).

Браница је затечен њеним исказом; док француски посланик отпочиње свој говор, пада киша. Убрзо, говор се заврши, народ се разиђе, а

на пустој, главној стази Калемегданског парка, сучелице Споменику захвалности Француској, само је један човек, погурених рамена, киснуо - као да није при себи (исто: 214).

Последица „победе стварности“ над фикцијом Анастаса Бранице јесте повлачење јунака Петровићевог романа у свет сопственог романа, у коме је идеална љубав једино могућа.

\section{5. Закључак}

Наведени примери показују да је посибилизам остварив као део уметничког поступка у коме се укрштају реалистичка и фантастичка мотивација. У Госпођи Бовари, једно време свет Емине лектире (фикције сентименталних и романтичарских романа) равноправан је, па и надређен „стварности“ њеног живота са Шарлом Боваријем у француској провинцији. У Ситничарници „Код срећне руке“ свет Браничине фикције (романа који пише) надређен је „стварности“ света романа, све док се време и простор његове фикције не укрсте са временом и простором „стварности“. Тада „стварност“, као и у случају Госпође Бовари, односи превагу.

Актуализам не допушта преливање идеалне романтичне љубави сачињене по жељама писца-љубавника у свет стварности, макар тај свет био језичка конструкција стварности остварена техникама реализма. У Флоберовом роману, политички контекст уводи симболички и иронијски смисао који узвишену љубав сентименталних романа спушта у стварносне оквире сточног вашара и стајског ђубрива. У роману Горана Петровића, у равни читалачке рефигурације (3) текста, могуће је препознати симболички смисао сцене код Споменика Француској на Калемегдану. Смисао је потврђен контекстуализацијом сусрета идеалних 
љубавника - Србина и Францускиње. Политички говор министра идеализација је међудржавних односа, на исти начин као што је епистоларни роман идеализација љубави. Актуализам односи превагу: као што у „стварности“ романа Францускиња не препознаје вољеног Србина, тако у модерној политичкој и историјској стварности Француска не препознаје Србију као савезницу.

Свет „стварности“ је створен реалистичким уметничким поступком, док је „фикција фикције“ остварена поступцима фантастичког приповедања. Све је то део уметничке игре и вештине и тада је могуће да фикција (фикција фикције) буде онтолошки равноправна стварности (стварности фикције) - као у теорији посибилизма. Као што показују примери из доминантно реалистичког (Госпођа Бовари) и доминантно постмодернистичког романа (Ситничарница „Код срећне руке“), актуализам има превагу у односу на посибилизам, ако се, као у првом случају, уметник одлучи да иронизује сентименталистичке и романтичарске књижевне поступке, или, као у другом случају - он одлучи да на тај начин мотивише поступке свог јунака и посредно, у симболичкој равни, пружи критику савременог друштва.

\section{Лumepamypa}

Илић, А. (1984). О реализму, Предговор. О реализму. Илић, А. (ур.). Београд: Просвета / Нолит / Завод за уџбенике и наставна средства. 7-31.

Илић, А. (2016). Поговор. Квас, К. Границе реализма. Београд: Завод за уџбенике. 251-258.

Петровић, Г. (2001). Ситничарница „Код срећне руке“. Београд: Народна књига / Алфа.

Томашевски, Б. (1972). Теорија књижевности: поетика. Београд: Српска књижевна задруга.

*

Doležel, L. (1980). Truth and Authenticity in Narrative. Poetics Today, 1, 3, 7-25.

Doležel, L. (2008). Heterokosmika. Beograd: Službeni glasnik.

Jakobson, R. (1986). Dva aspekta jezika i dve vrste afazičkih smetnji. Metafora, figure i značenje. Kojen, L. (ur.). Beograd: Prosveta. 211-235.

Kvas, K. (2011). Istina i poetika. Novi Sad: Akademska knjiga.

Lewis, D. (1979). Counterfactuals. The Possible and the Actual: Readings in the Metaphysics of Modality. Loux, M. J. (ed.). Ithaca: Cornell University Press. 182-189.

Ryan, M. (1991). Possible Worlds, Artificial Intelligence and Narrative Theory. Bloomington: Indiana University Press.

Flober, G. (2015). Gospođa Bovari. Beograd: Vulkan. 


\section{Kornelije Kvas}

University of Belgrade, Faculty of Philology

\section{REALISTIC MOTIVATION, ACTUALISM AND POSSIBILISM}

\section{- Summary -}

Aleksandar Ilić defined realistic motivation as a narrative based on the parallelism between the events and characters of a literary work and the events and characters of empirical reality. The modern theory distinguishes actualism, which gives ontological priority to the real world by separating it from a set of all other possible worlds, and possibilism, as an ontological equalization of the real world within a set of all other possible worlds. The paper analyzes the love scenes of Flaubert's novel Madame Bovary and the novel Sitničarnica "Kod srećne ruke" by Goran Petrović in the political context. The paper aims to determine the relevance of actualism and possibilism, especially concerning the realistic literary process. Aleksandar Ilić's reflections on the relationship between reality and fiction provide an understanding of contemporary theories of actualism and possibilism.

Keywords: realism, Aleksandar Ilić, Doležel, actualism, possibilism, Flaubert, Goran Petrović. 